\title{
A new parasitoid of the Erythrina Gall Wasp, Quadrastichus erythrinae Kim (Hymenoptera: Eulophidae)
}

\author{
JOHN LA SALLE ${ }^{1}$, MOHSEN RAMADAN ${ }^{2} \&$ BERNARR R. KUMASHIRO ${ }^{2}$ \\ ${ }^{1}$ CSIRO Entomology, GPO Box 1700, Canberra, ACT 2601, Australia, john.lasalle@csiro.au \\ ${ }^{2}$ Hawaii Department of Agriculture, 1428 S. King St., Honolulu, Hi 96814-2512, USA
}

\begin{abstract}
Aprostocetus exertus La Salle (Hymenoptera: Eulophidae: Tetrastichinae) is described as a parasitoid of the invasive Erythrina Gall Wasp, Quadrastichus erythrinae Kim (Hymenoptera: Eulophidae: Tetrastichinae). The description is based on material originally collected in Tanzania and South Africa. This species is described because of its potential as a biological control agent against the Erythrina Gall Wasp.
\end{abstract}

Key words: Hymenoptera, Eulophidae, invasive species, Quadrastichus, parasitoid, Aprostocetus, Erythrina, Fabaceae

\section{Introduction}

Coral trees (Fabaceae: Erythrina spp.) are highly valued trees which are found throughout tropical regions of the world, with about 120 species in the genus (Mabberly 2008). They are used as ornamentals in landscaping, for windbreaks and for soil and water conservation, as well as playing an important role in folk traditions and indigenous medicine (Hartwell 1967-1971, List \& Horhammer 1969-1979, Perry 1980, Rotar et al. 1986, Yang et al. 2004, Gates \& Delvare 2008). The Erythrina Gall Wasp (EGW), Quadrastichus erythrinae Kim (Eulophidae: Tetrastichinae), induces galls on the leaves, petioles, twigs and shoots of several species of coral trees. It was first recorded from La Réunion, Mauritius and Singapore (Kim et al. 2004), has subsequently spread rapidly so that its range now includes Hawaii, Taiwan, Hong Kong, China, India, Thailand, American Samoa, Guam, Okinawa, Japan, Florida (USA) (Yang et al. 2004, Heu et al. 2006, Faiza et al. 2006, Uechi et al. 2007, Gates \& Delvare 2008), and it has the potential for even greater range expansion in the future (Li et al. 2006). Severe EGW infestations can cause curling of young shoots, defoliation, and even death of afflicted trees (Yang et al. 2004, Heu et al. 2006). Its impact in Hawaii has been particularly devastating, where it is destroying and threatening with extinction the endemic species, E. sandwicensis $\mathrm{O}$. Deg. (Gramling 2005). If it continues to spread in Japan, it could have a similar effect on the endemic $E$. boninensis Tuyama (Uechi et al. 2007).

The origin of EGW could only be speculated upon in earlier works (Kim et al. 2004, Yang et al. 2004,) but it is now clear that it is originally from East Africa. It was already known that a group of Quadrastichus species induced galls on Erythrina in Africa (van Staden et al. 1977, La Salle unpublished, Prinsloo pers. comm., Prinsloo \& Kelly 2009). Foreign exploration undertaken by the Hawaii Department of Agriculture has confirmed that this group of Quadrastichus species which induce galls on Erythrina is larger than previously expected, with species throughout subtropical Africa. It has also confirmed that $Q$. erythrinae does occur naturally in Tanzania, where it has a complex of natural enemies which have potential for the biological control of this pest. One of these species, Eurytoma erythrinae Gates \& Delvare, was recently described (Gates \& Delvare 2008), and the description of another is being published in a companion paper (Prinsloo \& Kelly, 2009). This paper describes a third potential biological control agent of EGW. 
Several species of Eulophidae are known to induce galls, and these have been reviewed by La Salle (2005). There is a growing list of eulophids which have become invasive within the last two decades, and these include: Oncastichus goughi Headrick \& La Salle on Geraldton wax, Chamelaucium uncinatum Schauer (Headrick et al. 1995, Gates \& Schauff 2005), Epichrysocharis burwelli Schauff \& Garrison on eucalypts (Schauff \& Garrison 2000), Ophelimus maskelli (Ashmead) on eucalypts (Protasov et al. 2007b), Leptocybe invasa Fisher \& La Salle on eucalypts (Mendel et al. 2004), as well as the tetrastichines Moona spermophaga Kim \& La Salle and Leprosa milga Kim \& La Salle, both of which induce galls in eucalypt seed capsules (Kim et al. 2005, Kim \& La Salle 2008).

\section{Biological control opportunities}

While gall inducers have not been the usual target for biological control introductions, there is no reason not to expect that success can be achieved. The chestnut gall wasp, Dryocosmus kuriphilus Yasumatsu (Hymenoptera: Cynipidae), was successfully controlled in Japan by Torymus sinensis Kamijo (Hymenoptera: Torymidae), which was introduced from China for that purpose (Moriya et al. 2003). Since then, there is every indication that successful control of the eucalyptus gall wasp Ophelimus maskelli (Ashmead) (Eulophidae: Ophelimini) is underway in the Mediterranean Basin due to the introduction of Closterocerus chamaeleon (Girault) (Eulophidae: Entedoninae) (Rizzo et al. 2006, Mendel et al. 2007, Protasov et al. 2007a, b, De Marzo 2007). Additionally, two species of parasitoids, Quadrastichus mendeli Kim \& La Salle, and Selitrichodes kryceri Kim \& La Salle, have recently been released and established in Israel in an attempt at biological control of another invasive gall former, Leptocybe invasa (Kim et al. 2008). It is still too early to tell if this will result in successful control.

It is interesting to note that in the case of Ophelimus maskelli, both the invasive pest and the main natural enemy are in the same family (Eulophidae), while with Leptocybe invasa the pest and main natural enemies are even within the same subfamily (Eulophidae: Tetrastichinae). With EGW it is possible that we will have another example of an invasive pest and an introduced natural enemy from the same subfamily.

\section{Material and Methods}

\section{Taxonomy}

Terminology used in this paper is taken from Gibson (1997) and Graham (1987). OOL, ocellar-ocular distance; POL, post-ocellar distance; CC, costal cell; SMV, submarginal vein; MV, marginal vein; STV, stigmal vein; PMV, postmarginal vein; F1-3, funicular segment 1-3.

Acronyms used in the text are as follows. ANIC, Australian National Insect Collection, CSIRO Entomology, Canberra, Australia; BMNH, Natural History Museum, London, UK; BPBM, Bernice P. Bishop Museum, Honolulu, Hawaii, USA; NMK, National Museums of Kenya, Nairobi, Kenya; SANC, South African National Collection of Insects, Plant Protection Research Institute, Pretoria, South Africa; USNM, United States National Museum of Natural History, Washington, D.C., USA.

\section{Aprostocetus exertus La Salle sp. nov.}

(Figs 1-16)

Diagnosis. This species is easily recognized by the exerted part of the ovipositor and postcercale, which are slightly longer than the combined length of the head plus body. This character, coupled with the almost completely white fore and middle coxae, should make it unmistakeable.

Description. Female (Figs 1-3). Body length $1.45-1.75 \mathrm{~mm}$ from head to base of exerted part of ovipositor and extension of $\mathrm{T} 7$. 
Head metallic green to blue, palps yellow. Antenna with scape yellow (may be brownish apically), flagellum yellow to light brown. Mesosoma mainly metallic green to blue; some of the sutures between mesosomal segments may be yellow, particular the mesopleural plates and scapula. Legs white; fore and mid coxae white, with small basal brown spot; hind coxa brown, with white spot apically. Gaster brown with green to blue shine, a yellow spot dorsally on the first gastral tergite, and a white to yellow medial triangle dorsally on the last gastral tergite just anterior to the cerci.

Head (Fig. 7). POL about 3 times as long as OOL; LOL subequal to or slightly longer than OOL. Face with weak frontofacial suture just ventral to median ocellus. Scrobal depression with weak median suture dorsally and median carina or projection ventrally. Torulus located at middle of face; slightly above the lower margin of eye; apex scape not exceeding vertex.

Gena only slightly swollen and malar sulcus straight or very slightly curved. Clypeal margin strongly bidentate. Mouth only slightly wider than length of malar space.

Antenna (Fig. 13) with 3 anelli and 3 funicular segments. Anelli closely appressed, the second anellus smallest, the third anellus subquadrate, and may have setae on external margin. All funicular segments slender and longer than broad. F1 3.6-4.0 times longer than wide, F2 2.6-2.9 times longer than wide; F3 2.1-2.5 times longer than wide (F1: F2: F3 = 1.0: 0.7-0.8: 0.6-0.7). Clava 3 segmented, $2.0-2.15$ times longer than F3.

Mesosoma (Figs 8-10). Pronotum short in dorsal view, mainly in vertical plane. Mid lobe of mesoscutum with weak median line; with 2-4 (generally 3 ) strong, semi-erect adnotaular setae on each side; notaulus quite deep. Scutellum with distinct submedian and sublateral lines; anterior pair of setae located slightly posterior to middle; posterior pair of setae located near posterior margin. Propodeum shorter medially than median length of dorsellum; without distinct median carina; without paraspiracular carina; outer rim of propodeal spiracle partially covered by a raised flap of callus; spiracular depression open to anterior margin of propodeum. Callus with 2 setae.

Gaster (Figs 11-12) with the ultimate gastral segment (T7) greatly extended so that the length of the postcercale (that region of the last gastral segment posterior to the cerci) is longer than the combined length of the head plus body. What appears to be the exerted part of the ovipositor thus consists of the ovipositor and ovipositor sheaths, plus the extended last gastral tergite. This exerted part of the ovipositor 1.85-2.3 times as long as gaster; 1.15-1.3 times as long as gaster plus mesosoma. Apex of hypopygium extending less than half the length of gaster. Cercus with the longest setae distinctly longer than remaining setae, and slightly curved.

Wing (Fig 15). Submarginal vein with 2(-3) dorsal setae; tapering apically and joining parastigma distally to proximal end of parastigma. Marginal vein not swollen. Veins light brown to brown. Wing hyaline, with some light infuscation present near apex of stigmal vein, and at junction of basal and cubital veins. Postmarginal vein less than 0.25 length of stigmal vein. Costal cell apically with $2-4$ setae on underside of wing. Marginal vein relatively long in comparison to other veins; costal cell: marginal vein: stigmal vein: postmarginal vein $=0.7-0.85: 1.0: 0.15-0.2: 0.05-0.1$. Postmarginal vein $0.3-0.5$ length of stigmal vein. Cubital line of setae extending to basal vein or slightly basal to junction with basal vein (speculum closed behind). Subcubital line of setae not extending basal of apical margin of speculum.

Male. Body length 1.0-1.6 mm.

Body color almost the same as female; although with a larger white to yellow area at the base of the gaster. Antenna (Fig. 14) with 3 anelli; and 4 funicular segments which are all longer than broad; without whorls of long setae. Ventral plaque situated near apex of scape, length less than 0.25 length of scape. Genitalia often distinctly extended, exerted part of genitalia may equal length of gaster (fig. 16).

Type material. Holotype ${ }_{+}$: laboratory culture, Hawaii. Originally from TANZANIA, Arusha, Masai Camp Village, 27.i.2006, M. Ramadan, ex Erythrina abyssinica galls (ANIC).

Paratypes: $58 \uparrow, 55 \hat{\jmath}$. Same data as Holotype $(3 \uparrow, 7 \hat{\jmath}$ ANIC; $2 \uparrow, 2 \hat{\jmath} \mathrm{BMNH}, 2 \uparrow, 2 \hat{\jmath} \mathrm{SANC}, 2 \uparrow, 2 \hat{\jmath}$ USNM). South Africa, KwaZulu-Natal Prov., Pietermaritzburg, University Botanic Gardens, $29^{\circ} 36^{\prime} S$

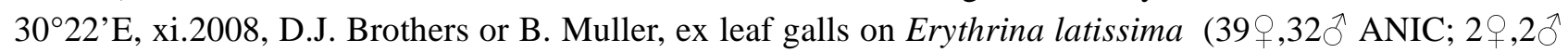

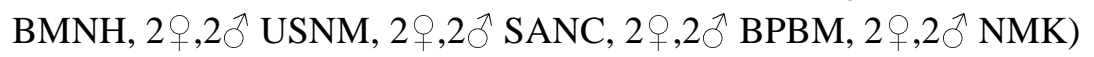




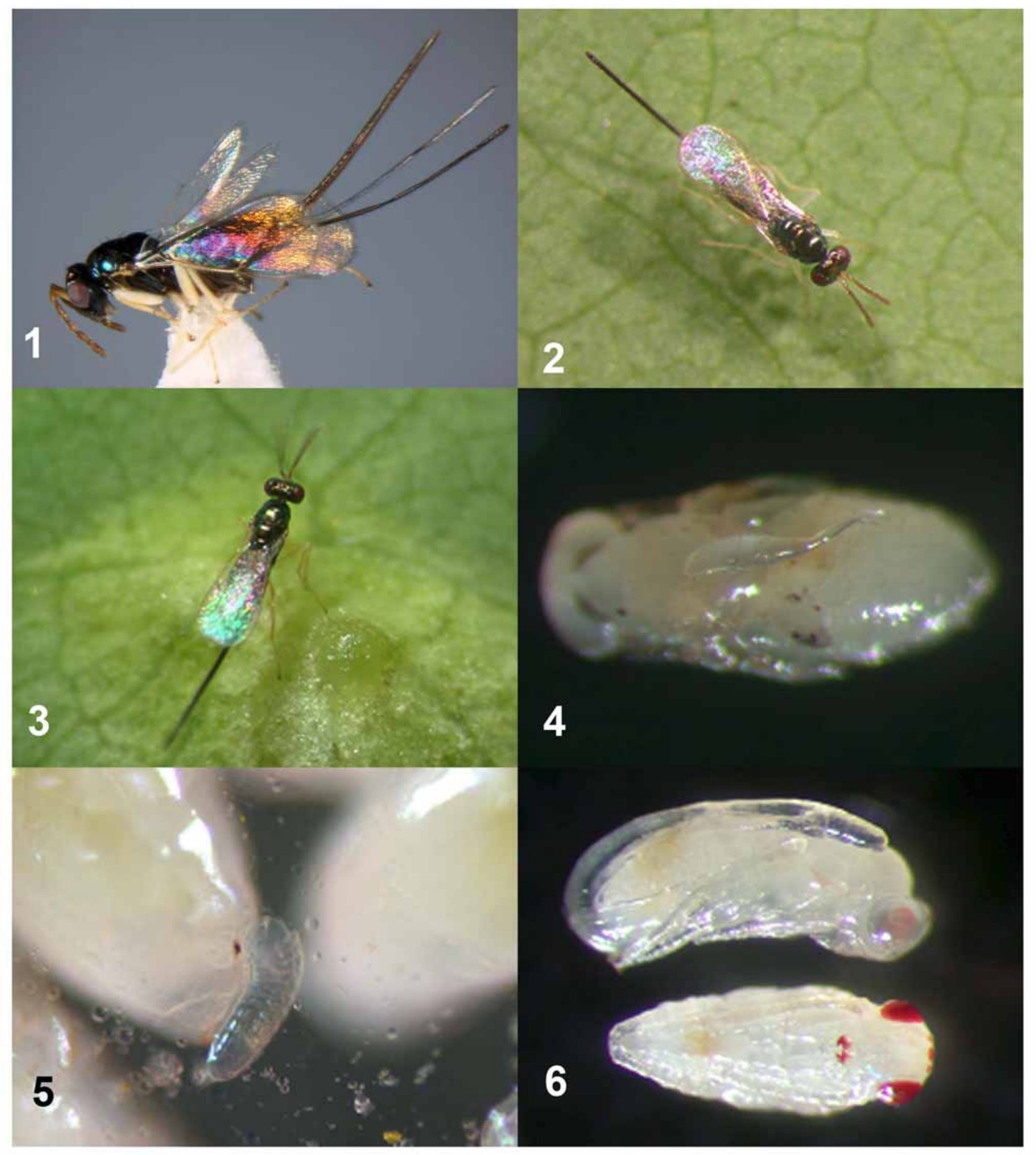

PLATE 1. Aprostocetus exertus La Salle. Fig. 1. $q$ Habitus. Figs 2-3. Female wasp searching for galls. Fig. 4. A. exertus egg on EGW pupa. Fig. 5. A. exertus larva feeding externally on EGW larva. Fig. 6. A. exertus pupae: female (above) and male (below).

Biology. Foreign exploration work searching for EGW parasitoids in East Africa was undertaken by one of us (MR), and revealed that Aprostocetus exertus is one of three main parasitoids in Tanzania reducing the populations of the gall wasps of Erythrina species. The other two species are Eurytoma erythrinae Gates \& Delvare (Gates \& Delvare 2008), and an Aprostocetus species being described in a companion paper by Prinsloo \& Kelly (2009). Field observations showed that A. exertus was not the dominant parasitoid at any surveyed locality in Tanzania; however it is an important component of the parasitoid guild because it is present at very low population levels of the gall wasps, and under a very harsh environmental condition. 
Because of its exerted long ovipositor, it has the ability to reach for galls deep in the stems of Erythrina that other parasitoids can not reach. Also, it is known to attack EGW under native conditions, as it was found attacking Quadrastichus erythrinae in Erythrina abyssinica in the Morogoro province in Tanzania.

Biological studies undertaken by the Hawaii Department of Agriculture have shown that this species is ectoparasitic, and will attack both larvae and pupae (Figs 4-5). Specimens from South Africa emerged from leaf galls on Erythrina latissima (see Prinsloo \& Kelly 2009).
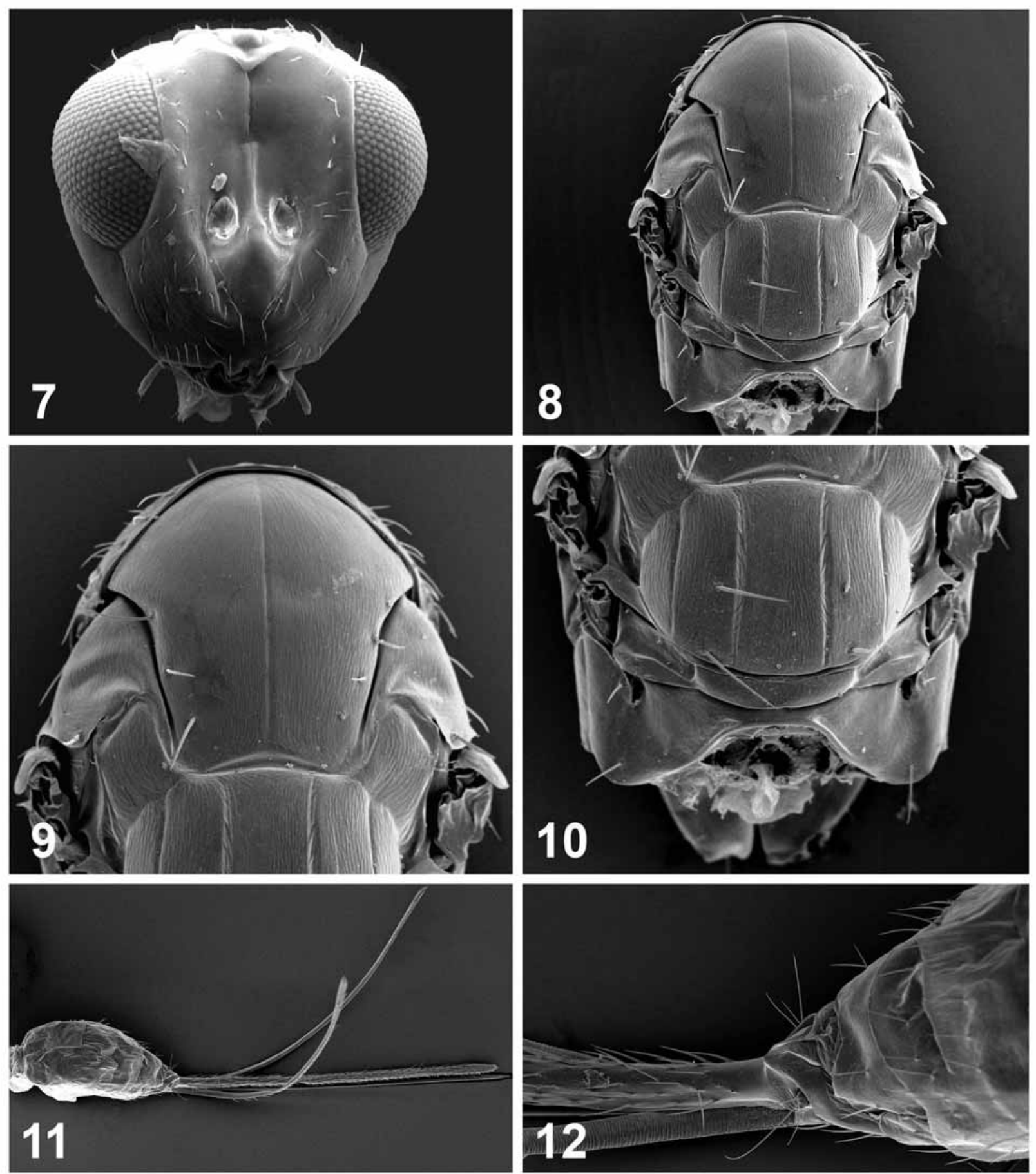

PLATE 2. Aprostocetus exertus La Salle $q$. Fig. 7. Head, frontal view. Fig. 8. Mesosoma, dorsal view. Fig. 9. Mesoscutum, dorsal view. Fig. 10. Scutellum and propodeum, dorsal view. Fig. 11. Gaster and ovipositor, lateral view. Fig. 12. Apex of gaster, base of postcercale, lateral view. 

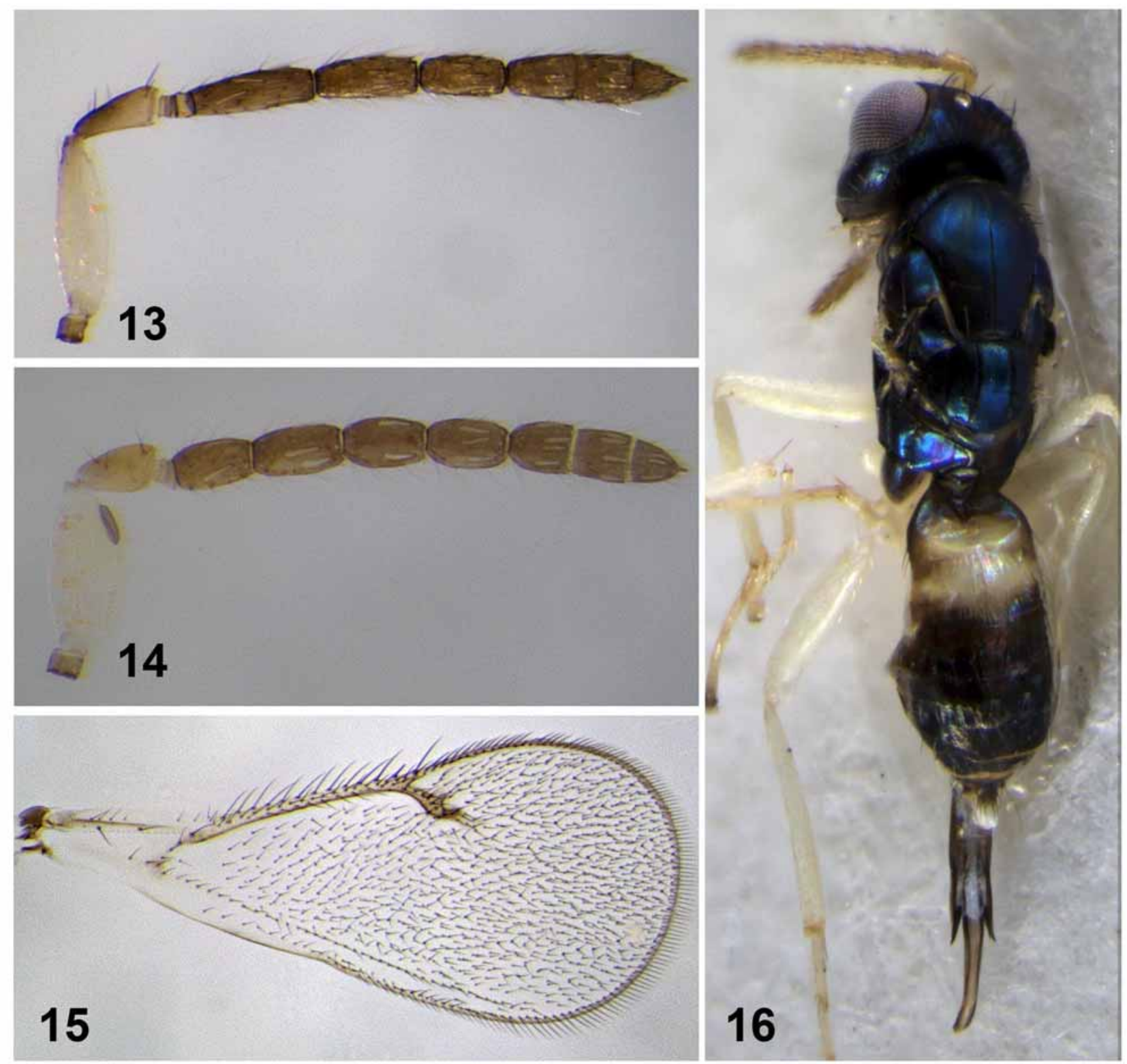

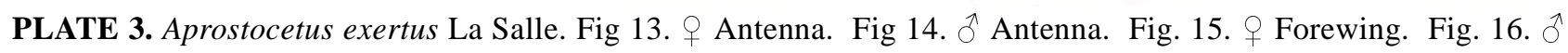
Habitus (wings removed), showing exerted genitalia.

Distribution. Africa: Tanzania, South Africa.

Etymology. The species name exertus is indicative of the extremely long and exerted ovipositor in this species.

Discussion. Aprostocetus is the largest genus in the Tetrastichinae (indeed, one of the largest genera in the Chalcidoidea), and it is biologically and morphologically diverse. Its identity in a modern sense was established by Graham $(1987,1991)$, and this interpretation of the genus has been followed by subsequent authors (e.g. Bouček 1988, La Salle 1994, Schauff et al. 1997). Currently the genus contains 6 subgenera (Graham 1987, La Salle 1994).

Aprostocetus exertus is treated in this paper as belonging to the subgenus Aprostocetus, but it does not completely agree with previous definitions of this group, and appears to share some characters with the subgenus Ootetrastichus. Graham (1987) distinguished Ootetrastichus from Aprostocetus s.s. as follows: midlobe of mesoscutum usually without a median line; subcubital line of setae reaching or nearly reaching basal vein; speculum small; propodeal spiracle generally small, with or without their outer rim partially covered by a raised flap on the callus; ovipositor sheaths slightly to greatly exerted; always with one of the 
cercal setae distinctly longer than the others; usually with 3 or more setae on the SMV, but occasionally with 2 (or even 1); generally elongate, brightly metallic species. A. exertus displays a combination of these characters, so that it does not comfortably fit in either Ootetrastichus or Aprostocetus ss. Clearly, there are some research opportunities remaining in African tetrastichines.

Biologically, Ootetrastichus seem to form a distinct group in that species are egg parasitoids of Hemiptera (Delphacidae, Cicadellidae), Orthoptera (Gryllidae), Odonata and Coleoptera (Dytiscidae), and some species can parasitize eggs in aquatic situations. There is, however, one exception: the African Aprostocetus (Ootetrastichus) theionerus (Masi) is a hyperparasitoid on stem borers (La Salle 1993).

\section{Acknowledgments}

We would like to thank G. Prinsloo and J. Kelly for making information on the biology and specimens of $A$. exertus available to us for this study. We thank Nicole Fisher for her assistance with illustrations. We would also like to thank two anonymous reviewers for their valuable comments on the manuscript.

\section{References}

Bouček, Z. (1988) Australasian Chalcidoidea (Hymenoptera): A Biosystematic Revision of Genera of Fourteen Families, with a Reclassification of Species. CAB International, Wallingford, UK, 832 pp.

De Marzo, L. (2007) Reperimento del parassitoide Closterocerus chamaeleon (Girault) in Basilicata e Puglia (Hymenoptera Eulophidae). Bollettino di Zoologia Agraria e di Bachicoltura, Serie II 39, 231-237.

Faiza M.H., Prathapan K.D., Anith K.N., Mary C.A., Lekha M. \& Rini C.R. (2006) Erythrina gall wasp Quadrastichus erythrinae, yet another invasive pest new to India. Current Science, 90, 1061-1062.

Gates, M. \& Delvare, G. (2008) A new species of Eurytoma (Hymenoptera: Eurytomidae) attacking Quadrastichus spp. (Hymenoptera: Eulophidae) galling Erythrina spp. (Fabaceae), with a summary of African Eurytoma biology and species checklist. Zootaxa, 1751, 1-24.

Gates M.W. \& Schauff M.E. (2005) The first report of Oncastichus goughi (Hymenoptera: Eulophidae): An introduced pest of waxflower (Myrtaceae: Chamelaucium uncinatum) from South America. Entomological News, 116, $115-116$.

Gibson, G.A.P. (1997) Chapter 2. Morphology and Terminology. In: Gibson, G.A.P., Huber, J.T. \& Woolley, J.B. (Eds), Annotated Keys to the Genera of Nearctic Chalcidoidea (Hymenoptera). National Research Council Research Press. Ottawa, Ontario, Canada, pp. 16-44.

Graham, M.W.R. de V. (1987) A reclassification of the European Tetrastichinae (Hymenoptera: Eulophidae), with a revision of certain genera. Bulletin of the British Museum (Natural History) Entomology, series 55, 1-392.

Graham, M.W.R. de V. (1991) A reclassification of the European Tetrastichinae (Hymenoptera: Eulophidae): Revision of the Remaining Genera. Memoirs of the American Entomological Institute, 49, 1-322.

Gramling C. (2005) Hawaii's coral trees feel the sting of foreign wasps. Science, 310, 1759-1850.

Hartwell, J.L. (1967-1971) Plants used against cancer. A survey. Lloydia, 30-34.

Headrick, D.H., La Salle, J., \& Redak, R.A. (1995) A new genus of Australian Tetrastichinae (Hymenoptera: Eulophidae): an introduced pest of Chamelaucium uncinatum (Myrtaceae) in California. Journal of Natural History, 29, 1029-1036.

Heu R.A., Tsuda D.M., Nagamine W.T., Yalemar J.A. \& Suh T.H. (2006) Erythrina Gall Wasp Quadrastichus erythrinae Kim (Hymenoptera: Eulophidae). State of Hawaii Department of Agriculture.

Available from: http://www.hawaiiag.org/hdoa/npa/npa05-03-EGW.pdf. [Accessed December 5, 2008].

Kim I.K., Delvare G. \& La Salle J. (2004) A New Species of Quadrastichus (Hymenoptera: Eulophidae): A Gallinducing Pest on Erythrina (Fabaceae). Journal of Hymenoptera Research, 13, 243-249.

Kim, I.-K., McDonald, M.W. \& La Salle, J. (2005) Moona, a new genus of tetrastichine gall inducers (Hymenoptera: Eulophidae) on seeds of Corymbia (Myrtaceae) in Australia. Zootaxa, 989, 1-10.

Kim, I.-K. \& La Salle, J. (2008) A new genus and species of Tetrastichinae (Hymenoptera: Eulophidae) inducing galls in seed capsules of Eucalyptus. Zootaxa, 1745, 63-68.

Kim, I.-K., Mendel, Z., Protasov, A., Blumberg, D. \& La Salle, J. \& (2008) Taxonomy, biology and efficacy of two Australian parasitoids of the eucalyptus gall wasp, Leptocybe invasa Fisher \& La Salle (Hymenoptera: Eulophidae: Tetrastichinae). Zootaxa, 1910, 1-20. 
La Salle, J. (1993) Aprostocetus (Ootetrastichus) theioneurus (Masi): a hyperparasitoid of the cereal stem-borer Chilo partellus in Africa (Hymenoptera: Eulophidae; Lepidoptera: Pyralidae). Zoologische Mededelingen Leiden, 67, 445-451.

La Salle, J. (1994) North American genera of Tetrastichinae (Hymenoptera: Eulophidae). Journal of Natural History, 28, $109-236$.

La Salle, J. (2005) Biology of gall inducers and evolution of gall induction in Chalcidoidea (Hymenoptera: Eulophidae, Eurytomidae, Pteromalidae, Tanaostigmatidae, Torymidae). In: Raman, A., Schaefer, C.W. \& Withers, T.M. (Eds), Biology, ecology, and evolution of gall-inducing arthropods. Science Publishers, Inc., Enfield, New Hampshire, USA, pp. 507-537

Li, H.M., Xiao, H., Peng, H., Han, H.X. \& Xue, D.Y. (2006) Potential global range expansion of a new invasive species, the Erythrina Gall Wasp, Quadrastichus erythrinae Kim (Insecta: Hymenoptera: Eulophidae). The Raffles Bulletin of Zoology, 54, 229-234.

List, P.H. \& Horhammer, L. (1969-1979) Hager's handbuch der pharmazeutischen praxis. Vols 2-6. Springer-Verlag, Berlin.

Mabberly, D.J. (2008) Mabberley's Plant-Book. 3rd Edition. Cambridge University Press, Cambridge, UK. 1040 pages.

Mendel, Z., Protasov, A., Fisher, N. \& La Salle, J. (2004) The taxonomy and natural history of Leptocybe invasa (Hymenoptera: Eulophidae) gen \& sp. nov., an invasive gall inducer on Eucalyptus. Australian Journal of Entomology, 43, 101-113.

Mendel, Z., Protasov, A., Blumberg, D., Brand, D., Saphir, N., Madar, Z. \& La Salle, J. (2007) Release and Recovery of parasitoids of the Eucalyptus gall wasp Ophelimus maskelli in Israel. Phytoparasitica, 35, 330-332.

Moriya, S., Shiga, M. \& Adachi, I. (2003) Classical biological control of the chestnut gall wasp in Japan. In: Proceedings of the First International Symposium on Biological Control of Arthropods, Honolulu, Hawaii, 14-18 January, 2002, pp. 407-415.

Perry, L.M. (1980) Medicinal plants of east and southeast Asia. MIT Press, Cambridge, 632 pp.

Prinsloo, G.L. \& Kelly, J. (2009) The tetrastichinae wasps (Hymenoptera: Chalcidoidea: Eulophidae) associated with galls on Erythrina species (Fabaceae) in South Africa, with the description of five new species. Zootaxa, 2083, 27-45.

Protasov, A., Blumberg, D., Brand, D., La Salle, J. \& Mendel, Z. (2007a) The basis for biological control of the eucalyptus gall wasp Ophelimus maskelli (Ashmead): taxonomy and biology of the parasitoid Closterocerus chamaeleon (Girault), with information on its establishment in Israel. Biological Control, 42, 196-206.

Protasov, A., La Salle, J., Blumberg, D., Brand, D., Saphir, N., Assael, F., Fisher, J. \& Mendel, Z. (2007b) Biology, revised taxonomy and impact on host plants of Ophelimus maskelli, an invasive gall inducer on Eucalyptus spp. in the Mediterranean area. Phytoparasitica, 35, 50-76.

Rizzo M.C., Lo Verde G., Rizzo R., Buccellato V. \& Caleca V. (2006) Introduzione di. Closterocerus sp. in Sicilia per il controllo biologico di Ophelimus maskelli Ashmead (Hymenoptera: Eulophidae) galligeno esotico sugli eucalypti. Bollettino di Zoologia Agraria e di Bachicoltura, Serie II 38, 237-248.

Rotar, P., Joy, R. \& Weissich, P. (1986) "Tropic Coral” tall erythrina. University of Hawaii, College of Tropical Agriculture, Human Resources Research Extension Series 072, 1-10.

Schauff, M.E., La Salle, J. \& Coote, L.D. (1997) Eulophidae. In: Gibson, G.A.P., Huber, J.T. \& Woolley, J.B. (Eds), Annotated Keys to the Genera of Nearctic Chalcidoidea (Hymenoptera). National Research Council Research Press. Ottawa, Ontario, Canada, pp. 327-429.

Schauff, M.E. \& Garrison, R. (2000) An introduced species of Epichrysocharis (Hymenoptera: Eulophidae) producing galls on Eucalyptus in California with notes on the described species and placement of the genus. Journal of Hymenoptera Research, 9, 176-181.

Uechi, N., Takumi, U., \& Yukawa, J. (2007) Detection of an invasive gall-inducing pest, Quadrastichus erythrinae (Hymenoptera: Eulophidae), causing damage to Erythrina variegata L. (Fabaceae) in Okinawa Prefecture, Japan. Entomological Science, 10, 209-212.

van Staden, J., Davey, J.E. \& Noel, A.R.A. (1977) Gall formation in Erythrina latissima. Zeitschrift für Pflanzenphysiol, 84, 283-294.

Yang M.M., Tung G.S, La Salle J. \& Wu M.L (2004) Outbreak of erythrina gall wasp on Erythrina spp. (Fabaceae) in Taiwan. Plant Protection Bulletin, 46, 391-396. 